\title{
Effect of neem (Azadirachta indica) leaves infusion on growth performance and
} carcass quality of broiler chickens

${ }^{1}$ Eggbeyale, L. T., ${ }^{2}$ Uza, O., ${ }^{1}$ Ayoola, A. A., ${ }^{3}$ Sobayo, R. A. ${ }^{1}$ Adeleye, O. O., ${ }^{1}$ Ayo-Ajasa, O. Y., ${ }^{4}$ Adewole, F. A., ${ }^{1}$ Ojetunji, O. C. and ${ }^{1}$ Oguntayo, I. E.

${ }^{\prime}$ Department of Animal Production and Health,

Federal University of Agriculture, P.M.B. 2240, Abeokuta, Nigeria.

${ }^{2}$ Department of Animal Production and Health,

Federal University of Agriculture, P.M.B. 2373, Makurdi, Benue State, Nigeria.

${ }^{3}$ Department of Animal Nutrition, Federal University of Agriculture, P.M.B. 2240, Abeokuta, Nigeria.

${ }^{4}$ Institute of Food Security, Environmental Resources and Agricultural Research, Federal University of Agriculture, P.M.B. 2240, Abeokuta, Nigeria.

Corresponding author:*egbeyalelt@funaab.edu.ng; 08060743664

\begin{abstract}
This study was conducted to determine the effect of neem leaf infusion on growth parameters, carcass characteristics and meat quality of broiler chicken. One hundred and sixty, seven days old broiler chicks of cob strain were used for the experiment which was laid out in a completely randomized design (CRD). Each group was sub-divided into four replicates of 10 birds. The chicks in group 1 served as control and antibiotics were administered to them while 0.1, 0.2 and 0.3\% concentration of neem leaf infusion were administered to bird on groups 2, 3 and 4, respectively. The period of experiment was six weeks. The birds were fed ad libitum. One bird close to average final weight was selected randomly in each replicate and was slaughtered at $42^{\text {nd }}$ day of the experiment. Meat samples from breast muscle of the bird were subjected to cooking weight loss, refrigeration weight loss and sensory evaluation. The data obtained were subjected to one-way Analysis of Variance. Results revealed that there were no significant ( $p>0.05$ ) effects of neem leaf infusion on weight gain and feed conversion ratio while water intake was influenced $(p<0.05)$ at the starter phase across the treatment groups. It was only feed intake that was influenced $(P<0.05)$ by the Neem leaf infusion $(N L I)$ at the finisher phase. The heart was the only parameter that was significantly $(p<0.05)$ affected among the carcass parameters. The cooking loss increased $(P<0.05)$ with higher concentration of the infusion while refrigeration weight loss percentages were similar $(P>0.05)$ across the treatments. The result on Sensory evaluation showed that only colour, tenderness and overall flavour were significantly $(P<0.05)$ influenced. The study concluded that administration of aqueous Neem (Azadirachta indica) leaf infusion in drinking water of broiler chicken as alternative to antibiotics did not pose any adverse threat on the performance and meat quality of broiler chicken.
\end{abstract}

Keywords: neem leaf, infusion, carcass quality, broiler chicken

\section{L'Effet de l'infusion de feuilles de neem (Azadirachtaindica) sur la performance de croissance et la qualité de carcasse des poulets de gril}

\section{Résumé}

Cette étude a été menée pour déterminer l'effet de l'infusion de feuilles de neem sur les paramètres de croissance, les caractéristiques de la carcasse et la qualité de la viande du 
poulet de gril. Cent soixante poussins de poulet à griller de sept jours de souche d'épi ont été utilisés pour l'expérience qui a été présenté dans une conception complètement randomisée (le 'CRD'). Chaque groupe a été subdivisé en quatre répliques de 10 oiseaux. Les poussins du groupe 1 ont servi de contrôle et des antibiotiques leur ont été administrés tandis que 0,1, 0,2 et $0,3 \%$ de concentration d'infusion de feuilles de neem ont été administrés à l'oiseau sur les groupes 2, 3 et 4, respectivement. La période d'expérience était de six semaines. Les oiseaux ont été nourris ad libitum. Un oiseau dont le poids final est proche de la moyenne a été sélectionné au hasard dans chaque réplique et a été abattu au 42 e jour de l'expérience. Des échantillons de viande prélevés sur le muscle mammaire de l'oiseau ont été soumis à la perte de poids de la cuisson, à la perte de poids de réfrigération et à l'évaluation sensorielle. Les données obtenues ont fait l'objet d'une analyse à sens unique de la variance. Les résultats ont révélé qu'il n'y avait pas d'effets significatifs $(p>0,05)$ de l'infusion de feuilles de neem sur le gain de poids et le rapport de conversion des aliments pour animaux, tandis que la prise d'eau a été influencée $(p<0,05)$ à la phase de démarrage dans tous les groupes de traitement. Ce n'est que la prise d'aliments qui a été influencée $(P<0,05)$ par l'infusion de feuilles neem (NLI) à la phase finale. Le cour était le seul paramètre qui était significativement $(p<0,05)$ affecté parmi les paramètres de la carcasse. La perte de cuisson a augmenté $(P<0,05)$ avec une concentration plus élevée de l'infusion tandis que les pourcentages de perte de poids de réfrigération étaient similaires $(P>0,05)$ à travers les traitements. Le résultat de l'évaluation sensorielle a montré que seules la couleur, la tendresse et la saveur globale étaient significativement influencées $(P<0,05)$. L'étude a conclu que l'administration de feuilles de neem (Azadirachta indica) dans l'eau potable du poulet de gril comme alternatif aux antibiotiques ne posait aucune menace négative sur la performance et la qualité de la viande du poulet de gril.

Mots-clés : feuille de neem, infusion, qualité carcasse, poulet de gril

\section{Introduction}

Poultry is one of the fastest means to achieving appreciable improvement in the nutritional standard of the populace because of its short generation interval, quick turnover rate and relatively low capital investment (Ani and Okeke, 2011). Attempts had been made to ensure that broiler chickens attain table size earlier through the use of additives. The main objective of adding feed additives is to boost animal performance by increasing their growth rate, better feed conversion efficiency, greater livability and lowered mortality in poultry birds. These feed additives are termed as "growth promoters" and often called as non-nutrient feed additives (Singhks and Panda, 1992). Antibiotic growth promoters have been helpful in improvement of growth performance and feed conversion ratio in poultry (Miles et al., 2006). However, constant treatment of poultry with antibiotic may result in residues of these substances in poultry products and bacteria resistance against treatments in human body. Due to such threats to human health, use of antibiotics in poultry is banned (Owens et al., 2008). Therefore, properties of other herbs, such as antioxidant, antiviral, or immune-modulatory properties and their effects on performance and digestive health needed to be harnessed.

Medicinal plants infusions were developed and proposed for use in food as natural antimicrobials (Hsieh and Mau, 2001). Beneficial effects of herbal infusions or active substances in animal nutrition includes the stimulation of appetite and feed intake, the improvement of endogenous digestive enzyme secretion, activation of immune response and antibacterial, anti- 
viral, antioxidant and anthelminthic actions. Generally, plant infusions have no problem of antimicrobial resistance (Tipu et al., 2006) and broilers fed on herbal feed additives were accepted well by consumers (Hernandez et al., 2004). Aqueous infusion of Neem leaves has a good therapeutic potential as anti-hyperglycemic agent, antibacterial agent and could be used for controlling airborne bacterial contamination in the residential premise (Mishra et al., 2013). It was shown that Neem leaves infusion acts as a growth promoter (Landy et al., 2011), improves performance and haematological parameters (Nayaka et al., 2013) and immune response (Jawad et al., 2013) in broilers. Due to paucity of information on the effect of neem leaf infusion on performance and meat quality of broiler chicks, this study was designed to investigate the effect of water infusion of neem leaves on growth performance and carcass quality of broiler chickens.

\section{Materials and methods \\ Experimental site}

The rearing of birds took place at the Poultry Units of the Teaching and Research Farm, while the meat quality section was carried out at the Meat Processing Laboratory, Department of Animal Production and Health, College of Animal Science and livestock Production, of Federal University of Agriculture Abeokuta (FUNAAB).

\section{Source and preparation of the infusion}

Fresh neem (Azadirachta indica) leaves were harvested, rinsed thoroughly with water to remove all the dirt from it then pounded in a mortar with pestle to increase the surface area for better infusion. The pounded leaves were weighed on the sensitive scale at 1,2 and $3 \mathrm{~g}$, which were needed for the experiment. The weighed freshly pounded neem leaves were added to clean water (at room temperature) at 1,2 and $3 \mathrm{~g}$ of neem leaves to 1 litre of water and thereafter was left for 12 hours at room temperature and was sieve before it was offered to the birds.

\section{Experimental design}

A Completely Randomized Design (CRD) was adopted for this experiment. The one hundred and sixty, 7-day old broiler chicks of Cobb strain were allocated into four treatments of 40 chicks and ten chicks per replicate. The period of the experiment was six weeks. Treatment 1 (Control) was administered antibiotics (Enrofloxacin at the manufacture's recommendation), Treatment 2 had $0.1 \%$ of neem infusion in drinking water, Treatment 3 had $0.2 \%$ of neem infusion in drinking water and Treatment 4 had $0.3 \%$ of neem infusion in drinking water. Starter broiler diet of $23 \%$ $\mathrm{CP}$ and $11.47 \mathrm{MJ} / \mathrm{Kg}$ was supplied $\mathrm{ad}$ libitum for the first three weeks while finisher broiler diet of $20.10 \% \mathrm{CP}$ and 11.62 $\mathrm{MJ} / \mathrm{Kg}$ was supplied during the last three weeks of the experiment.

\section{Data collection}

The initial weight of the birds was taken on replicate basis at the commencement of the study while subsequent weights were taken on weekly. Feed intake was determined by subtracting the amount of leftover feed from the quantity of feed given. At the $42^{\text {nd }}$ day of the experiment, one bird of average weight of each replicate was weighed for carcass evaluation. The birds were starved overnight, slaughtered, scalded in warm water and defeathered manually. The birds were weighed to obtain their dressed carcass weight. The cut-up parts (head, neck, back, breast, thigh, drumstick, and shanks), organs (heart, liver, lungs, gizzard, proventiculus, intestines), and abdominal fat were weighed and expressed as percentage of live weight. After dressing, breast meat sample of 54.13-54.80g from each broiler chicken was cooked separately at $70^{\circ} \mathrm{C}$ for 15 minutes in a water bath (Egbeyale et al., 
2012). The difference between the weights before and after cooking gave the cooking weight loss of the meat samples. Meat samples of another set of $51.20-54.50 \mathrm{~g}$ were cut from the breast muscles of the slaughtered broiler chicken. Each sample was weighed and labeled according to the treatment before being stored in a refrigerator at about $10^{\circ} \mathrm{C}$ for 24 hours (Egbeyale et al., 2012).

\section{Sensory evaluation}

For sensory evaluation, a uniform size of cooked chicken breast meat was sliced into cubes and the cooked chicken breast meat was labeled according to each treatment and samples were allowed to cool before serving the panel. Eight educated panelists were isolated from each other, so as to prevent communication and each panelist was asked to rinse his/her mouth with ordinary water after each sample testing to avoid any carry over effects. The panelist evaluated the meat colour, flavour, juiciness, aroma, texture, saltiness and overall acceptability. The evaluators were asked to score the sample on nine points scale according to Egbeyale et al. (2012)

\section{Statistical analysis}

Data were subjected to one-way Analysis of Variance (ANOVA) and differences in means were separated using Duncan Multiple Range Test (SAS 2012) at 5\% significance level.

\section{Results}

The effect of aqueous neem leaf infusion (NLI) on growth performance of broiler chicks is presented in Table 1 . There were no significant $(\mathrm{p}>0.05)$ differences across the treatments on the measured growth indices except water intake at chick phase. The water intake of birds on inclusion level of 0.2 and $0.3 \%$ neem leaf infusion was similar and significantly $(\mathrm{p}<0.05)$ higher than the control group. The birds on $0.1 \%$ NLI had similar values of their counterparts on control, 0.2 and $0.3 \%$ NLI. The effect of aqueous infusion of neem leaf on growth parameters of broiler chicken at finisher phase is presented in Table 2. The results showed that the varying levels of NLI influenced $(\mathrm{P}<0.05)$ only feed intake among all the growth parameters. The highest $(p<0.05)$ feed intake was recorded from bird on $0.1 \%$ neem leaf infusion though similar to those on control and $0.2 \% \mathrm{NLI}$ while the least value was obtained from birds on $0.3 \% \mathrm{NLI}$

Table 1: Effect of Neem leaf infusion on growth performance of broiler chicken at starter phase

\begin{tabular}{lllll}
\hline & \multicolumn{4}{c}{ Inclusion level of NLI (\%) } \\
Parameter & 0 & 0.1 & 0.2 & 0.3 \\
\hline Initial weight $(\mathrm{g})$ & $121.70 \pm 0.32$ & $122.10 \pm 0.43$ & $121.33 \pm 0.34$ & $121.75 \pm 0.35$ \\
final weight $(\mathrm{g})$ & $530.00 \pm 8.90$ & $541.81 \pm 11.28$ & $560.28 \pm 12.91$ & $565.56 \pm 9.65$ \\
weight gain $(\mathrm{g})$ & $408.30 \pm 8.90$ & $419.71 \pm 11.28$ & $438.95 \pm 12.91$ & $443.81 \pm 9.65$ \\
daily weight gain $(\mathrm{g} / \mathrm{d})$ & $14.58 \pm 0.32$ & $14.99 \pm 0.40$ & $15.68 \pm 0.46$ & $15.85 \pm 0.34$ \\
total feed intake $(\mathrm{g})$ & $1211.86 \pm 29.73$ & $1231.28 \pm 33.67$ & $1317.59 \pm 58.28$ & $1265.88 \pm 46.51$ \\
daily feed intake $(\mathrm{g} / \mathrm{d})$ & $57.71 \pm 1.42$ & $58.63 \pm 1.60$ & $62.74 \pm 2.78$ & $60.28 \pm 2.21$ \\
total water intake $(\mathrm{ml})$ & $1761.63 \pm 72.23^{\mathrm{b}}$ & $1802.02 \pm 35.44^{\mathrm{ab}}$ & $1942.88 \pm 39.70^{\mathrm{a}}$ & $1956.62 \pm 56.54^{\mathrm{a}}$ \\
daily water intake $(\mathrm{ml} / \mathrm{d})$ & $83.89 \pm 3.44^{\mathrm{b}}$ & $85.81 \pm 1.68^{\mathrm{ab}}$ & $92.52 \pm 1.89^{\mathrm{a}}$ & $93.17 \pm 2.69^{\mathrm{a}}$ \\
feed conversion ratio & $2.97 \pm 0.11$ & $2.93 \pm 0.01$ & $3.01 \pm 015$ & $2.86 \pm 0.15$ \\
\hline
\end{tabular}

$<,<;$ Means on the same row with different superscripts are significantly $(\mathrm{p}<0.05)$ different 
Egbeyale, Uza, Ayoola, Sobayo, Adeleye, Ayo-Ajasa, Adewole, Ojetunji and Oguntayo

Table 2: Effect of Neem leaf infusion on growth performance of broiler chickens at finisher phase

\begin{tabular}{lllll}
\hline & & \multicolumn{3}{c}{ Inclusion level of NLI (\%) } \\
Parameter & 0 & 0.1 & 0.2 & 0.3 \\
\hline initial weight $(\mathrm{g})$ & $530.00 \pm 8.90$ & $541.81 \pm 11.28$ & $560.28 \pm 12.91$ & $565.56 \pm 9.65$ \\
Final weight $(\mathrm{g})$ & $1683.34 \pm 43.06$ & $1622.62 \pm 5501$ & $1551.19 \pm 41.40$ & $1545.70 \pm 79.04$ \\
Weight gain $(\mathrm{g})$ & $1153.34 \pm 39.93$ & $1080.82 \pm 52.07$ & $990.92 \pm 41.69$ & $980.15 \pm 82.30$ \\
Daily weight gain $(\mathrm{g} / \mathrm{d})$ & $54.92 \pm 1.90$ & $51.47 \pm 2.48$ & $47.19 \pm 1.99$ & $46.67 \pm 3.92$ \\
Total feed intake $(\mathrm{g})$ & $3096.84 \pm 60.01^{\mathrm{ab}}$ & $3198.72 \pm 100.77^{\mathrm{a}}$ & $3015.76 \pm 55.25^{\mathrm{ab}}$ & $2860.62 \pm 102.36^{\mathrm{b}}$ \\
Daily feed intake $(\mathrm{g} / \mathrm{d})$ & $147.47 \pm 2.86^{\mathrm{ab}}$ & $152.32 \pm 4.80^{\mathrm{a}}$ & $143.61 \pm 2.63^{\mathrm{ab}}$ & $136.22 \pm 4.87^{\mathrm{b}}$ \\
Total water intake $(\mathrm{ml})$ & $5801.74 \pm 162.19$ & $16484.22 \pm 10421.66$ & $5881.11 \pm 198.32$ & $5489.27 \pm 169.31$ \\
Daily water intake $(\mathrm{ml} / \mathrm{d})$ & $276.27 \pm 7.72$ & $784.96 \pm 496.27$ & $280.05 \pm 9.44$ & $261.39 \pm 8.06$ \\
Feed conversion ratio & $2.69 \pm 0.11$ & $2.97 \pm 0.12$ & $3.05 \pm 0.09$ & $2.98 \pm 0.27$ \\
\hline
\end{tabular}

$<,<$, Means on the same row with different superscripts are significantly $(\mathrm{P}<0.05)$ different

The effect of neem leaf infusion on carcass characteristics of broiler chicken is presented in Table3. There were no significant $(\mathrm{P}<0.05)$ differences in all the parameters on carcass and relative organ weight evaluated except heart. The highest $(\mathrm{p}<0.05)$ value of heart was recorded frombird on $0.3 \%$ neem leaf infusion while the least value was obtained from control group.

Table 3: Carcass characteristics of broiler chicken administered with neem leaf infusion

\begin{tabular}{lllll}
\hline \multicolumn{5}{c}{ Inclusion level of NLI (\%) } \\
Parameter & 0 & 0.1 & 0.2 & 0.3 \\
\hline Live weight (g) & $1744.25 \pm 49.10$ & $1654.50 \pm 51.20$ & $1594.75 \pm 49.75$ & $1631.75 \pm 66.41$ \\
Pluck weight (g) & $1620.00 \pm 50.99$ & $1525.00 \pm 53.15$ & $1475.00 \pm 49.92$ & $1515.00 \pm 70.42$ \\
Eviscerated weight (g) & $1330.00 \pm 51.96$ & $1230.00 \pm 64.55$ & $1190.00 \pm 56.86$ & $1210.00 \pm 90.37$ \\
Dress weight (g) & $1145.00 \pm 68.50$ & $1030.00 \pm 59.16$ & $1000.00 \pm 54.77$ & $1035.00 \pm 56.79$ \\
Dressing percentage \% & $65.49 \pm 2.09$ & $62.13 \pm 1.99$ & $62.58 \pm 1.60$ & $63.33 \pm 0.89$ \\
Cut-parts (\% of liveweight) & $10.79 \pm 0.38$ & $10.40 \pm 0.50$ & $9.88 \pm 0.25$ & $10.22 \pm 0.24$ \\
Drumstick & $10.31 \pm 0.52$ & $10.33 \pm 0.35$ & $10.16 \pm 0.42$ & $10.62 \pm 0.07$ \\
Thigh & $17.39 \pm 0.95$ & $16.44 \pm 1.53$ & $17.06 \pm 1.02$ & $17.62 \pm 0.75$ \\
Breast & $15.95 \pm 0.81$ & $15.05 \pm 0.23$ & $14.86 \pm 0.99$ & $17.29 \pm 1.61$ \\
Back & $8.31 \pm 0.23$ & $8.69 \pm 0.21$ & $8.56 \pm 0.40$ & $8.04 \pm 0.49$ \\
Wing & & & & \\
Organs (\% of liveweight) & $2.93 \pm 0.59$ & $2.27 \pm 0.13$ & $2.51 \pm 0.27$ & $2.60 \pm 0.04$ \\
Liver & $0.69 \pm 0.08$ & $0.61 \pm 0.04$ & $0.57 \pm 0.03$ & $0.63 \pm 0.03$ \\
Lung & $0.41 \pm 0.01^{\mathrm{b}}$ & $0.43 \pm 0.03^{\text {ab }}$ & $0.45 \pm 0.02^{\mathrm{ab}}$ & $0.49 \pm 0.02^{\mathrm{a}}$ \\
Heart & $3.54 \pm 0.24$ & $3.31 \pm 0.25$ & $2.71 \pm 0.79$ & $2.86 \pm 0.73$ \\
Gizzard & $0.58 \pm 0.10$ & $0.63 \pm 0.10$ & $0.61 \pm 0.08$ & $0.61 \pm 0.02$ \\
Proventriculus & $7.67 \pm 1.14$ & $8.58 \pm 0.62$ & $9.26 \pm 1.26$ & $8.30 \pm 0.54$ \\
Whole intestine & & & & \\
\hline
\end{tabular}

$<,<$ Means on the same row with different superscripts are significantly $(\mathrm{P}<0.05)$ different

The effect of neem leaf infusion (NLI) on cooking and refrigeration weight losses of broiler chicken is present in Table 4. Cooking weight loss (CWL) was significantly $(\mathrm{p}<0.05)$ influenced. The CWL of meat from birds on $0.3 \%$ ANLI were significantly higher than the control.
However, the meat from birds that drank water containing 0.1 and $0.2 \%$ ANLI recorded values similar to both control and $0.3 \% \mathrm{ANLI}$ group. The refrigeration weight loss and percentage refrigeration loss did not show any significant $(\mathrm{p}>0.05)$ different among the treatments. 
Table 4: Effect of neem (Azadirachta indica) leave infusion on cooking and refrigeration loss of broiler chicken

\begin{tabular}{lllll}
\hline & \multicolumn{4}{c}{ Inclusion level of NLI (\%) } \\
Parameters & 0 & 0.1 & 0.2 & \multicolumn{1}{c}{0.3} \\
\hline Cooking & & & & \\
Weight before cooking (g) & $54.80 \pm 0.47$ & $54.13 \pm 0.78$ & $55.33 \pm 1.36$ & $54.30 \pm 1.11$ \\
Weight after cooking (g) & $49.15 \pm 0.37$ & $47.13 \pm 0.95$ & $48.90 \pm 1.26$ & $46.98 \pm 1.36$ \\
Cooking weight loss (g) & $5.65 \pm 0.37^{\mathrm{b}}$ & $7.00 \pm 0.61^{\mathrm{ab}}$ & $6.43 \pm 0.18^{\mathrm{ab}}$ & $7.33 \pm 0.55^{\mathrm{a}}$ \\
Percentage weight loss (\%) & $10.30 \pm 0.61^{\mathrm{b}}$ & $12.94 \pm 1.12^{\mathrm{ab}}$ & $11.62 \pm 0.27^{\mathrm{ab}}$ & $13.52 \pm 1.11^{\mathrm{a}}$ \\
& & & & \\
Refrigeration & & & & \\
Weight before refrigeration (g) & $53.80 \pm 1.35$ & $51.20 \pm 0.58$ & $54.08 \pm 0.91$ & $54.50 \pm 0.55$ \\
Weight after refrigeration (g) & $52.75 \pm 1.18^{\mathrm{a}}$ & $48.75 \pm 1.03^{\mathrm{b}}$ & $51.50 \pm 1.19^{\mathrm{a}}$ & $52.50 \pm 0.87^{\mathrm{a}}$ \\
Refrigeration weight loss (g) & $1.05 \pm 0.35$ & $2.45 \pm 0.73$ & $2.58 \pm 1.52$ & $2.00 \pm 0.34$ \\
Percentage weight loss (\%) & $1.93 \pm 0.62$ & $4.80 \pm 1.45$ & $4.68 \pm 2.79$ & $3.69 \pm 0.68$ \\
\hline
\end{tabular}

${ }_{a}^{a, b ;}$ Means on the same row with different superscripts are significantly $(\mathrm{p}<0.05)$ different

*the initial weight of the refrigeration was used as co-variate

The effect of aqueous neem leaf infusion (ANLI) on sensory characteristics of broiler chicken meat is present in Table 5. The juiciness, meaty flavour, saltiness and overall acceptability were not significantly ( $>0.05)$ influenced across parameters measured, while colour, tenderness and overall flavour were significantly $(\mathrm{p}<0.05)$ influenced.

Table 5: Effect of neem (Azadirachta indica) leaves infusion on sensory quality of broiler chicken

\begin{tabular}{lllll}
\hline \multicolumn{4}{l}{ Inclusion level of NLI (\%) } \\
Parameters & 0 & 0.1 & 0.2 & 0.3 \\
\hline Colour & $5.14 \pm 0.22^{\mathrm{ab}}$ & $4.79 \pm 0.31^{\mathrm{ab}}$ & $5.50 \pm 0.23^{\mathrm{a}}$ & $4.32 \pm 0.35^{\mathrm{b}}$ \\
Juiciness & $5.39 \pm 0.30$ & $6.04 \pm 0.34$ & $6.11 \pm 0.24$ & $5.93 \pm 0.38$ \\
Tenderness & $5.14 \pm 0.38^{\mathrm{b}}$ & $5.71 \pm 0.35^{\mathrm{ab}}$ & $6.39 \pm 0.34^{\mathrm{a}}$ & $5.18 \pm 0.35^{\mathrm{b}}$ \\
Overall Flavour & $5.18 \pm 0.26^{\mathrm{ab}}$ & $4.86 \pm 0.30^{\mathrm{b}}$ & $5.75 \pm 0.28^{\mathrm{a}}$ & $5.07 \pm 0.33^{\mathrm{ab}}$ \\
Meaty Flavour & $6.14 \pm 0.29$ & $6.36 \pm 0.31$ & $6.50 \pm 0.20$ & $6.17 \pm 0.30$ \\
Saltiness & $5.04 \pm 0.28$ & $5.04 \pm 0.26$ & $4.54 \pm 0.20$ & $4.75 \pm 0.40$ \\
Overall acceptability & $5.18 \pm 0.33$ & $4.96 \pm 0.36$ & $5.68 \pm 0.32$ & $4.79 \pm 0.34$ \\
\hline
\end{tabular}

a,b; Means on the same row with different superscripts are significantly $(\mathrm{p}<0.05)$ different

\section{Discussion}

The similar effect of oral neem leaf infusion supplement and the conventional use of antibiotics observed in the final weight gain of broilers chicken at the starter and finisher phases could possibly be due to the antimicrobial properties of neem leaf, which helps to reduce the microbial loads of birds (Kale et al., 2003). The gain observed in mean body weight of the present study is in line with the findings of Nidaullah et al. (2010) that weight gain varied insignificantly in groups of broilers treated with aqueous infusions of certain medicinal herbs (garlic bulb, ginger rhizomes, and Neem leaves. The observed difference in water intake between the birds on the control group and those on neem leaf infusion at the starter phase could be due to presence of antinutritional substances in the infusion since terpenes and limonoids (Kabeh and Jalingo, 2007) as well as Azadirachtin (Ogbuewu et al., 2010) in neem are unpalatable and results in poor acceptability of Neem leaves. The significant difference in water consumption observed in this study agreed with Durrani et al. (2008) who reported a significant 
difference in the water intake of the broiler treated groups and the control. There was no significant difference in feed conversion ratio, this is an indication that the neem leaf infusion did not impair nutrient availability, digestion, absorption and utilization, however, Chakeravarty and Prasad (1991) and Durrani et al. (2008) reported better feed conversion ratio of broilers fed commercial ration and water containing Neem ( $A$. indica) infusion than others. The variation in the findings could be due to management system adopted, the strain of the broiler chick, age of the birds and the level of concentration of the neem leaf infusion which play key roles in performance of livestock.

The increase in the heart weight of the birds with increase in the concentration level of aqueous neem leaf infusion could probably be due to higher physiological activities triggered by the presence of anti-nutritional factors in the neem and their associate effects was also reported by Uchegbu et al. (2004). Feeding of neem products to poultry and other livestock had been reported to have significant increase in the organ weights of the heart, liver (Esonu et al., 2006; Uko and Kamlu, 2005; Uko and Kamalu, 2008) and the kidney (Musalia et al., 2000; Bawa et al., 2007).

The cooking loss values reported in this study are lower than the values reported by Gohar et al. (2012) who compared cooking loss in broiler and layer meat and reported that cooking loss in broiler meat was in the range of 15.55 to $36.00 \%$. The increase in the cooking weight losses with increasing levels of ANLI obtained in this study is in accordance with the results of the work of Ncube et al. (2018) who studied the effect of Acacia angustissima leaf meal on yield of carcass components and meat quality of broilers and reported that increasing levels of the leaf meal resulted in drier meat. High cooking loss also implies the less ability of the meat to hold water during processing and storage (Abu et al., 2015). According to Michalczuk et al. (2014), high meat cooking loss has an adverse effect on sensory perception as it reduces juiciness. The influence of ANLI on tenderness and overall flavour is consistent with results published by Jang et al. (2008) on the enhancement of flavour after feeding a mixture of herbal tree infusions to broilers. Similarly, the result agrees with Aderinola et al. (2013) who reported enhanced flavour of meat from Moringa oleifera-fed broilers. These similarities in juiciness and meaty flavour are in agreement with findings of Bonsu et al. (2012) who studied the medicinal response of broiler chickens to diets containing neem (Azadirachta indica) leaf meal. Egbeyale et al. (2012) in their study of meat qualities characteristics of broiler chicken fed varying levels of Ocimum gratissimum reported that parameters such as juiciness, saltiness and overall acceptability were not significantly influenced. However, the authors reported that overall flavour were significantly influenced which is in accordance with the results of this study.

\section{Conclusion and Recommendation}

It was concluded that oral administration of aqueous infusions of neem (Azadirachta indica) leaf up to $0.3 \%$ in the drinking water of broiler chicken could be used as a substitute for antibiotics without having adverse effect on growth performance, carcass characteristics and meat quality of broiler chicken.

\section{References}

Abu, O. A., Olaleru, I. F. and Omojola, A. B. 2015. Carcass characteristics and meat quality of broilers fed cassava peel and leaf meal as replacements for maize and soybean meal. Journal of Agricultural Veterinary Science, 8(3): 41-46.

Aderinola, O. A., Rafiu, T. A., Akinwumi, 
A. O., Alabi, T. A. and Adeagbo, $O$. A. 2013. Utilization of Moringa oleifera leaf as supplement in broiler diet. International Journal Food, Agriculture Veterinary Science, 3(3):94-102.

Ani, A. O. and Okeke, G. C. 2011. The performance of broiler birds fed varying dietary levels

of roasted pigeon pea (Cajanus cajan) seed meal. Pakistan Journal of Nutrition. 10(11): 1036-1040.

Bawa, G. S., Orunmuyi, M., Agbaji, A. S. Ladan, Z. and Okekeifi, U. O. 2007. Effect of Different Methods of Processing Neem (Azadirachta indica), seeds on performance of young Rabbits. Pakistan Journal of Nutrition 6(3): 212-216.

Bonsu, F. R. K., Kagya-Agyemang, J. K., Kwenin, W. K. J. and Zanu, H. K. 2012. Medicinal response of broiler chickens to diets containing Neem (Azadirachta indica) leaf meal, haematology and meat sensory analysis World Applied Science Journal, 19(6):800-805.

Chakarverty, A. and Parsad, J. 1991. Study on the effect of neem leaf infusion and neem and cake infusion on the performance of broiler chicks. Indian Poultry Advisor 24(9): 37-38.

Durrani, F. R., Chand N., Jan, M., Sultan, A., Durrani, Z. and A $k$ h t a r, S . 20068 . Immunomodulatory and growth promoting effects of Neem (Azadirachta indica) leaves infusion in broiler chicks. Sarhad Journal of Agriculture, 24(4), 655-659. http://www.aup.edu.pk/sj pdf/IM MUNOMODULATORY\%20AND \%20GROWTH\%20PROMOTING. pdf

Egbeyale, L. T., Sogunle, O. M., Adeleye, O. O., Oseni, M. A., Fajohunbo, G.
O., Oyeleye, A. M. and Oduwaye, S. A. 2012. Meat qualities characteristics of broiler chicken fed varying levels of Ocimum gratissimum. International Journal of Applied Animal Science, 1(2): 6367.

Esonu, B. O., Opara, M. N., Okoli, I. C., Obikaonu, H. O., Udedibie, C. and Iheshiulor, O. O. M. 2006. Physiological responses of laying birds to Neem (Azadirachta indica) leaf meal-based diets, body weight, organ characteristics and hematology. Online Journal of Health and Allied Sciences, 2(4) http//www.ojhas.org/issue 18/20062-4.htm 2006.

Gohar, R., Abdul, B., Inayat, U. R., Mudassir, K. and Sayed, A. K. 2012. Comparative study on cooking loss in broiler and layer meat. A project report submitted through the department of veterinary science, faculty of animal husbandry and veterinary science, to Sindh agriculture University Tandojam in connection with partial, fulfilment of the requirements for the Id subject. https://www.academia.edu/909547 1/comparative study on cooking loss in broiler and layer meat

Hernandez, F., Madrid. J., Garcia, V., Orengo, J. and Megias, M. D. 2004. Influence of two plant extracts on broiler performance digestibility and digestive organ size. Poultry Science, 83: 169-174. DOI: $10.1093 / \mathrm{ps} / 83.2 .169$

Hsieh, P. C. and Mau, J. L. 2001. Antimicrobial effect of various combinations of plant extracts. Food microbiology, 18: 35-43. DOI: $\underline{10.1006 / \text { fmic. } 2000.0376}$

Jang, A., Liu, X. D., Shin, M. H., Lee, S. K., Lee, J. H. and Jo, C. 2008. Anti- 
oxidative potential of raw breast meat from broiler chicks fed a dietary medicinal herb infusion mixture. Poultry Science, 87(11): $\begin{array}{lllllllll}2 & 3 & 8 & 0 & - & 2 & 3 & 8 & 9\end{array}$. https://www.sciencedirect.com/jour nal/poultry-science/vol/87/issue/11

Jawad. Z., Younus, M., Rehman, M. U., Maqbool, A., Munir, R., Muhammad, K., Korejo, R. A. and Qazi, I. H. 2013. Effect of Neem leaves (Azadirachta indica) on immunity of commercial broilers against newcastle disease and infectious bursal disease. African Journal of Agricultural Research, 8: $\begin{array}{lllllllll}4 & 5 & 9 & 6 & -4 & 6 & 0 & 3\end{array}$. D O I $: 10.5897 / A J A R 2013.7852$

Kabeh, J. D. and Jalingo, M.G. D.S.S. (2007). Exploiting neem (Azadirachta indica) Resources for improving the quality of Life in Taraba State, Nigeria. International Journal Agriculture and Biology; 560-853

Kale, B. P., Kothekar, M. A., Tayade H. P., Jaju, J. B., and Mateenuddin, M. 2003. Effect of aqueous infusion of Azadirachta indica leaves on hepatotoxicity induced by antitubercular drugs in rats. Indian Journal of Pharmacology, 35: 177180.

Landy, N., Ghalamkari, G., Toghiani, M. and Yazdi, F. F. 2011. Humoral immune responses of broiler chickens fed with antibiotic and neem fruit powder (Azadirachta indica) as feed additive supplemented diet. IPCBEE 3:153155.

Michalczuk, M., Lukasiewicz, M., Zdanowska-Sasiadek, $Z$. and Niemiec, J. 2014. Comparison of selected quality attributes of chicken meat as affected by rearing systems. Poultry Journal Food Nutrition
Science, 64 (2), 121-126.

Miles, R. D., Butcher, G. D., Henry, P. R., Littell, R. C. 2006. Effect of antibiotic growth promoters on broiler performance, intestinal growth parameters, and quantitative morphology. Poultry Science 85:476-485.

Mishra, A. Singh, M., Kumari, N., Jaiswal, N., Mahuar, P., Asthana, P., Dixit, P. 2013. Antibacterial effects of crude infusion of Azadirachta indica against Escherichia coli and Staphylococcus aureus. International Journal of Science, Environment and Technology, 2: 989-993.

Musalia, L. M., Anandan. S., Sastry V. R. B., and Agrawal, D. K. 2000. Ureatreated neem (Azadirachta indica) seed kernel cake as a protein supplement for lambs, Small ruminants Reserves, 35:107-116.

Nayaka, H. B. S. Umakantha, B., Ruban, S. W., Murthy, H. N. N. and Narayanaswamy, H. D. 2013. Performance and hematological parameters of broilers fed Neem, turmeric, vitamin $\mathrm{E}$ and their combinations. Emirates Journal of Food and Agriculture, 25: 483-488.

Ncube, S., Halimat, T. E., Chikosi, E. V. I. and Saidi, P. T. 2018. Effect of Acacia angustissima leaf meal on performance yield of carcass components and meat quality of broilers. South African Journal of Animal Science, Vol.48 (No.2).

Nidaullah, H., Durrani, F. R., Ahmad, S., Jan, I. U., and Gul, S. 2010. Aqueous infusion from different medicinal plants as anticoccidial, growth promotive and immunostimulant in broilers. $A R P N$ Journal Agriculture Biology Science, 5: 153-159. 
Ogbuewu, I. P., Uchegbu, M. C., Okoli, I. C. and Iloeje, M. U. 2010. Assessment of blood chemistry, weight gain and linear body measurements of pre-pubertal buck rabbits fed different levels of neem (Azadirachta indica A Juss) leaf meal. Chilean Journal of Agricultural Research, 70 (3):515520.

Owens, B., Tucker, L., Collins, M.A., McCracken, K.J., 2008. Effects of different feed additives alone or in combination on broiler performance, gut microflora and ileal histology. British Poultry Science. 49:202-212.

SAS, 2012. Statistical Analysis System, User's Guide. Statistical version 9.1th Statistical Analysis System Institute Inc. Cary, North Cariolina, United State of America.
Singh, K.S. and B. Panda, 1992. Poultry Nutrition. Kalyani Publisher, New Delhi, India, pp: 57-61

Tipu, M. A., Akhtar, M. S., Anjum, M. I. and Raja, M. L. 2006. New dimension of medicinal plants as animal feed. Pakistan Veterinary Journal, 26 (3): 144-148.

Uchegbu, M. C. Okoli, T. C. and Etuk, E. B, 2004. Preliminary Studies on Napoleona imperialis as livestock feed ingredient: proximate composition. Proceedings of the 36th Annual Conference of the Agricultural Society of Nigeria, FUT, Owerri, October 20 - 24, pp. $422-424$.

Uko, O. J. and Kamalu, T. N. 2008. Trend of food consumption and efficiency of broiler production with raw or heat-treated neem kernels, Archzootec. 57 (220): 489-496.

Uko, O. J. and Kamalu, T. N. 2005. Haematological Parameters and Weight Changes of Cockerels Fed Raw or Autoclaved Neem seed kernels in Diets. Nigerian Veterinaryjournal 26(1): 10-17.

Received: $10^{\text {th }}$ September, 2020 Accepted: $5^{\text {th }}$ January, 2021 